\title{
The Impact of Corporate Governance on the Financial Distress: Evidence from Pakistani Listed Companies
}

\author{
Ahmed Hassan Jamal* , Syed Zulfiqar Ali Shah \\ International Islamic University, Islamabad
}

\begin{abstract}
This study intends to assess how corporate governance affects the financial distress in non-financial listed companies in Pakistan. Sample of 53 companies was obtained from non-financial institutes listed in Pakistani stock exchange. Regression analysis is used to estimate the impact of explanatory variables including size of board, composition of board, audit committee independence and duality of CEO on the financial distress. The findings show that size of board, composition of board and CEO duality has a positive impact on Z-score of Pakistani listed firms. This implies that better the corporate governance practices in companies, lower will be the financial distress and vice versa.
\end{abstract}

\section{Introduction}

There has been a debate whether the corporate governance practices play a role in generating the financial returns to the owners and the other stakeholders (Parker et al., 2002). It also includes the ability of the firm to survive and revive from the times of financial distress. Hence, it has been an area of interest to understand whether the corporate governance practices impact the organizational ability to confront the period of financial distress.

Various studies in the past have found out that the attributes of corporate governance are having an association with the financial distress (Datta and Datta, 1995; Elloumi and Gueyie, 2001; Gilson, 1989). Corporate governance is defined a set of policies and regulations designed to direct and control the company (Cadbury Report, 1992). Prime objective of corporate governance is to serve the shareholders in the best way possible (Wajid and Shah, 2017). Hence, it can be said that better corporate governance will allow the companies to provide better strategic decision making and to reduce the state of financial distress within itself. Corporate governance includes overall code of corporate governance, policies and procedures for corporate reporting and mechanism for internal and external audit needs, in order to keep an independent observance on the method and affairs of the company and it is thought that this in turn will enhance the financial performance of the entity in short term, as well as the market value of shares of the company in the long term. It is therefore important to explore the impact that is exerted by the corporate governance practices in the period of fi-

*Corresponding author.

Email: hassan.jamal@aiou.edu.pk

http://www.jbrc.pk nancial distress. However, in this study the main area of concern will be the board's structure.

On the other hand, financial distress is a term that is used in negative connotation to express the financial position of an entity. Financial distress is often described in terms of default, failure, bankruptcy and unsuccessfulness of meeting financial objectives.

This study intends to identify and examine the relationship of the corporate governance practices on the financial distress faced by various Pakistani listed companies. This study will check the impact of different corporate governance practices individually on the financial distress of Pakistani listed companies. The current study is significant as hardly such study has been conducted among Pakistani listed companies. Furthermore, it aims to explore the impact of specific elements board's structure on the financial distress faced by Pakistani listed companies.

\section{Literature Review}

Li et al. (2008) found a negative relationship between the factors of corporate governance like board size, board composition and duality of CEO with the financial distress in the company. Lee and Yeh (2004) tested the association between corporate governance and financial distress in the Taiwanese context. They concluded that the probability of financial distress increases in the companies having weaker corporate governance practices.

Simpson and Gleason (1999) studied the relationship between board structure, ownership, and the fi- 
nancial distress in the banking industry. The results showed that probability of financial distress in lower when the Chairman and the CEO is one person. However, other factors of corporate governance were found insignificant in the study.

Hassan Al-Tamimi (2012) tested the relationship between the corporate governance and the financial distress on the UAE banks. He found out that there is a significant positive relationship between corporate governance and the level of financial distress. But he further argued that corporate governance in the UAE banks is not good enough. Elloumi and Gueyie (2001) studied the similar relationship and reported that inclusion of outside directors is a key factor in reducing the financial distress of an organization. He argued that the inside directors lack objectivity and independence. Hence, they don't always make decisions that are in the best interest of the shareholders. However, their study failed to find a relationship between the CEO duality and the financial distress.

Parker et al. (2002) also studied the role of corporate governance in increasing the likelihood of survival at the times of financial distress. They also argued that the corporate governance attributes influence the situation of financial distress in an organization.

Muranda (2006) studied that influence of corporate governance on financial distress on the financial sector of Zimbabwe. He argued that weaker boards tend to lead to weak internal system which in turn plays a significant role in increasing the financial distress in an organization. He also pointed out that corporate governance is not only a moral concept but an obligatory matter as well. Hence, the regulators must ensure the compliance on corporate governance requirements that may lead the firm to have strong decision making and vision at the times of financial distress.

$\mathrm{Li}$ et al. (2008) studied the relationship of independent board and agency cost on the financial distress in the Chinese listed companies. He assessed 404 Chinese listed companies for a period from 1998 to 2008. The results of his study were similar to the previous studies. He found out that agency cost and independent boards have a negative impact on probability of financial distress in Chinese listed companies. This means that the firms having the higher proportion of independent directors in their board have lesser probabilities of financial distress.

\subsection{Hypotheses Development}

\subsubsection{Board Size and Financial Distress}

Independent directors increase the experience level and the knowledge level in to the firm's board and hence strategic decision making of the company is significantly enhanced (Hillman and Dalziel, 2003). It is therefore argued that higher the board's size so will be the experience level and the education level in the board, which means that such firms have better capacity to make better strategic level decisions, consequently allowing the companies to gain competitive advantage in the industry. It is therefore believed that probability of financial distress is lesser in firms having larger board size compared to the firms having lower board size. Based on the above arguments, we construct the following hypothesis:

H1. Larger board size negatively affects the financial distress of a company

\subsubsection{Duality and Financial Distress}

Often when CEO of an organization is not able to perform as per the expectations of the company's board, the board has two options either to demote the $\mathrm{CEO}$ of the company or dismiss them. In case of financial distress or when CEO is unable to meet the expected performance, the evidence is more in support of dismissal of the CEO (Bhagat et al., 1999; Weisbach, 1988). In stronger boards, there is a split between the post of chairman and the $\mathrm{CEO}$ so that $\mathrm{CEO}$ can put his concentration purely on the operations and activities of the company rather than the rules and regulation issues (Mallette and Fowler, 1992). This in turn helps the companies to increase their performance and such companies are less likely to face the financial distress level. Hence, we propose the following hypothesis:

H2. CEO/Chairman duality has negative relationship with financial distress

\subsubsection{Composition of Board and Financial Dis- tress}

In order to have better strategic decision making and management, shareholders desire more nonexecutive directors in the board than the executive directors (Weisbach, 1988). This helps the companies to focus their decisions in the best interests of the shareholders and agency problem can be avoided. Boards having higher proportion of non-executive directors are keen to take aggressive decisions in case of bankruptcy or poor performance, such as change of $\mathrm{CEO}$, as their prime focus is to make decisions in the best interest of the shareholders rather than for the benefit of few key management individuals (Shivdasani, 2004). Such companies hence are more determined to operate smoothly and they plan well to avoid any situation of financial distress that may lead to a poor public image of the company. Therefore, following hypothesis has been developed:

H3. Higher proportion of the non-executive directors in the board will lead to lower financial distress in the company 


\subsubsection{Audit Committee Independence and Fi- nancial Distress}

Shareholders desire to have more independent directors in the company's board as compared to the executive directors so that the company can operate in the best interests of shareholders (Weisbach, 1988). Audit committee is one of the key committees that works under the board. Hence, it is ideal for the companies to have higher percentage of independent directors in the audit committee so that internal and external audit activities can be directed in the possible way. Moreover, there is higher chance that any adverse situation will be foreseen at appropriate times and the company can take timely steps to avoid any situation of financial distress. Therefore, we propose as follows:

H4. Higher percentage of independent directors in the audit committee will impact negatively to the financial distress level

\section{Theoretical Framework}

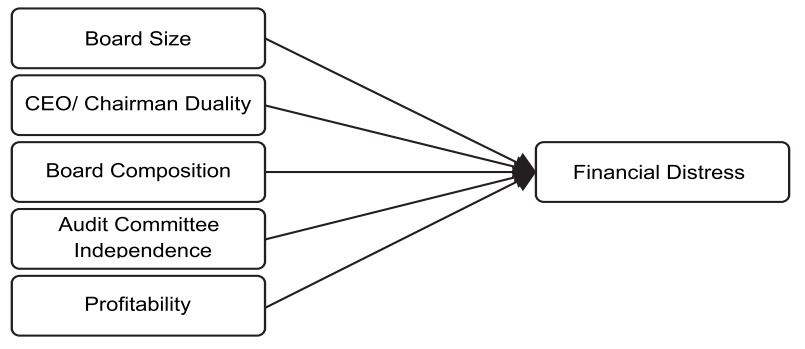

Figure 1: Theoretical framework.

\section{Methodology}

\subsection{Sample and Procedure}

The sample of the study consisted of 53 companies listed at Karachi stock exchange. Five years data were analyzed from 2010 to 2014.

The general statistical model for the study is given as follows:

$$
\begin{array}{r}
F D_{i t}=\alpha+\beta_{1}(B Z)_{i t}+\beta_{2}(B C)_{i t}+\beta_{3}(D U A L)_{i t} \\
+\beta_{4}(A C I)_{i t}+\beta_{5}(P R O F)_{i t}+\varepsilon_{i t}
\end{array}
$$

where

$F D=$ Financial Distress

$B Z=$ Size of Board

$B C=$ Composition of Board

$D U A L=$ Duality amongst CEO and Chairman

$A C I=$ Audit Committee Independence

$P R O F=$ Profitability

$\varepsilon=$ Error term

\subsection{Measure of Variables}

\subsubsection{Board Size}

Board size can be defined as the numerical strength of the company's board. Researchers argued that larger board size is likely to affect the business performance (Abor, 2007). Therefore, we have calculated board size as the natural $\log$ of total number of board members.

\subsubsection{Board Composition}

It is measured as the proportionate number of nonexecutive directors compared to the total board members. It is therefore calculated by dividing the number of non-executive directors with the total number of board members.

\subsubsection{Audit Committee Independence}

Audit committee independence shows the representative in the audit committee that is non-executives. Hence, it is calculated as the ratio of number of nonexecutive directors in the audit committee to the total number of directors in the audit committee.

\subsubsection{CEO/Chairman Duality}

To capture the effect of CEO/ Chairman Duality, we have used a Dichotomous variable in our research. Value " 1 " is given for the boards having different post for the CEO and the Chairman; otherwise the value is zero.

\subsubsection{Profitability}

Profitability is the controlled variable in the study. It is calculated through return of assets. ROA $=$ Profit After Tax $/$ Total Assets

\subsubsection{Financial Distress}

Altman, Z-score has been used as a proxy for the financial distress as Z-score model is considered as one of the most frequently used models for early prediction of financial distress (Yi, 2012). The original model introduced by Altman (1968) as a predictor of financial distress, and the score can be computed as follows:

$$
Z-\text { Score }=1.2 X_{1}+1.4 X_{2}+3.3 X_{3}+0.6 X_{4}+1.0 X_{5}
$$

where

$\mathrm{X}_{1}=$ Working Capital/Total Assets

$\mathrm{X}_{2}=$ Retained Earnings/Total Assets

$X_{3}=$ Earnings before Interest and Taxes/Total Assets

$\mathrm{X}_{4}=$ Market Value of Equity/Book Value of Total Debt

$\mathrm{X}_{5}=$ Sales $/$ Total Assets

It should be noted that there is a negative relationship between the calculated value of Z-Score and the 
Table 1: Summary of regression model outcomes

\begin{tabular}{lcccc}
\hline Variable & Coefficient & Std. Error & t-Statistic & Prob. \\
\hline C & 1.430707 & 0.142562 & 10.03565 & 0.0000 \\
ACI & -0.002693 & 0.100529 & -0.026786 & 0.9787 \\
BC & 0.170812 & 0.102203 & 1.671291 & $0.0959^{*}$ \\
BZ & 0.212840 & 0.068582 & 3.103452 & $0.0021^{* * *}$ \\
DUAL & 0.087486 & 0.039392 & 2.220937 & $0.0272^{* *}$ \\
PROF & 0.934269 & 0.272145 & 3.432982 & $0.0013^{* * *}$ \\
\hline R-squared & 0.291633 & Mean dependent var & 2.014091 & \\
Adjusted R-squared & 0.257504 & S.D. dependent var & 0.627717 & \\
S.E. of regression & 0.219897 & & & \\
Sum squared resid & 12.57217 & & & \\
F-statistic & 5.777813 & & & \\
Prob(F-statistic) & 0.000181 & & & \\
\hline Note:****** significance at 10,5 and 1 percent & & & \\
\hline
\end{tabular}

financial distress which implies that lower value of ZScore means there is more likelihood of bankruptcy. Altman (1968) modified the model and replaced the Market Value of Equity (in $\mathrm{X}_{4}$ ) by the Book Value of Equity. The modified model is defined as:

$$
\begin{array}{r}
Z-\text { Score }=0.717 X_{1}+0.847 X_{2}+3.107 X_{3}+0.42 X_{4} \\
+0.998 X_{5}
\end{array}
$$

\section{Results and Discussion}

Regression analysis was used to predict the empirical results of the study. The results of the study are shown in Table 1.

Before interpreting the results it must be kept in mind that dependent variable for the measure of financial distress in Altman Z-score. The higher the Z-score the lower will be the financial distress. Hence, the positive impact of any independent variable on the depen- dant variable will be interpreted as decrease in financial distress.

The $R^{2}$ explains that 29 percent change in the ZScore of a company is due to variations in the independent variables i.e. CEO duality, board independence, audit committee independence and the board size. The value of $R^{2}$ is low but this is majorly due to a fact that corporate governance practices are not optimal in most of the companies. The value of $\mathrm{R}$ square is expected to be higher if such study is tested in the countries with optimal corporate governance practices. The value of F-statistics is 5.777813, which is significant, showing that there is combined impact of independent variables on the Z-Score of a company.

Findings of the study suggest that board size, CEO duality and board composition are affecting the Z-score positively, which means higher these variables in a firm lower will be the level of financial distress in the firm. On the other hand, independence of audit committee's impact on Z-Score is insignificant, which implies that there is no impact of audit committee independence on 
the financial distress a firm is facing.

\section{Conclusion}

The study concludes that board size will reduce the level of financial distress in a company. The major reason of such phenomena is due to the fact that larger board sizes have higher level of competence in their board and hence such companies are able to make better financial decisions than otherwise.

The CEO and chairman duality also have resulted in decrease in financial distress in companies. It is because when the Chairman and CEO jobs are segregated the decision are made irrespective of biasness and tough decisions like replacing the CEO or directors are taken for the betterment of the company.

Board independence also has resulted in decrease in financial distress of a company as per statistical results. This is arguable because independent boards are more capable of taking best decisions for the companies that are in best interest of the shareholders and not the executives and management only.

On the other hand, audit committee independence does not have any impact on the financial distress of the companies in Pakistan. This is largely because of the fact that audit committees decision is dependent on the employees of the companies like internal audit related issues or the internal control implementation. Such employees are largely influenced by the management decisions and hence even an independent audit committee does not have control on the level of financial distress level in Pakistani listed companies.

\section{References}

Abor, J. (2007). Corporate governance and financing decisions of ghanaian listed firms. Corporate Governance: The International Journal of Business in Society, 7(1):83-92.

Altman, E. I. (1968). Financial ratios, discriminant analysis and the prediction of corporate bankruptcy. The Journal of Finance, 23(4):589-609.

Bhagat, S., Carey, D. C., and Elson, C. M. (1999). Director ownership, corporate performance, and management turnover. The Business Lawyer, pages 885-919.

Cadbury Report, A. (1992). Report of the committee on the financial aspects of corporate governance, volume 1. Gee.

Datta, S. and Datta, M. E. (1995). Reorganization and financial distress: An empirical investigation. Journal of Financial Research, 18(1):15-32.
Elloumi, F. and Gueyie, J.-P. (2001). Financial distress and corporate governance: an empirical analysis. Corporate Governance: The International Journal of Business in Society, $1(1): 15-23$.

Gilson, S. C. (1989). Management turnover and financial distress. Journal of Financial Economics, 25(2):241-262.

Hassan Al-Tamimi, H. A. (2012). The effects of corporate governance on performance and financial distress: The experience of uae national banks. Journal of Financial Regulation and Compliance, 20(2):169-181.

Hillman, A. J. and Dalziel, T. (2003). Boards of directors and firm performance: Integrating agency and resource dependence perspectives. Academy of Management Review, 28(3):383-396.

Lee, T.-S. and Yeh, Y.-H. (2004). Corporate governance and financial distress: Evidence from taiwan. Corporate Governance: An International Review, 12(3):378-388.

Li, H.-x., Wang, Z.-j., and Deng, X.-l. (2008). Ownership, independent directors, agency costs and financial distress: evidence from chinese listed companies. Corporate Governance: The International Journal of Business in Society, 8(5):622-636.

Mallette, P. and Fowler, K. L. (1992). Effects of board composition and stock ownership on the adoption of "poison pills". Academy of Management Journal, 35(5):1010-1035.

Muranda, Z. (2006). Financial distress and corporate governance in zimbabwean banks. Corporate Governance: The International Journal of Business in Society, 6(5):643-654.

Parker, S., Peters, G. F., and Turetsky, H. F. (2002). Corporate governance and corporate failure: a survival analysis. Corporate Governance: The International Journal of Business in Society, 2(2):4-12.

Shivdasani (2004). Best practices in corporate governance: what two decades of research reveals. Journal of Applied Corporate Finance, 16(2-3):29-41.

Simpson, W. G. and Gleason, A. E. (1999). Board structure, ownership, and financial distress in banking firms. International Review of Economics E Finance, 8(3):281-292.

Wajid, H. and Shah, S. A. (2017). The influence of corporate governance and ownership structure on capital structure of pakistani listed companies. Journal of Contemporary Management Sciences, 1(2):31-46.

Weisbach, M. S. (1988). The determinants of board composition. The RAND Journal of Economics, pages 589-606.

Yi, W. (2012). Z-score model on financial crisis early-warning of listed real estate companies in china: a financial engineering perspective. Systems Engineering Procedia, 3:153157. 